\title{
Populasi dan Asosiasi Marga Ficus di Gunung Tilu Kabupaten Kuningan Provinsi Jawa Barat
}

\author{
Yayan Hendrayana ${ }^{1}$, Ika Karyaningsih ${ }^{2}$, Nina Herlina ${ }^{3}$ \\ ${ }^{12}$ Dosen Prodi Kehutanan Fakultas Kehutanan Universitas Kuningan \\ yayan.hendrayana@uniku.ac.id \\ ika.karyaningsih@uniku.ac.id \\ ${ }^{3}$ Dosen Prodi Ilmu Lingkungan Fakultas Kehutanan Universitas Kuningan \\ nina.herlina@uniku.ac.id
}
APA Citation: Hendrayana, Y., Karyaningsih, I., Herlina, N. (2020). Populasi Dan Asosiasi Marga Ficus Di Gunung Tilu Kabupaten Kuningan Provinsi Jawa Barat. Quagga: Jurnal Pendidikan dan Biologi. 12(2), 163-169. doi: 10.25134/quagga.v12i2.2797.

\begin{abstract}
Abstrak: Marga Ficus mempunyai peranan sebagai sumberdaya kunci pada ekosistem hutan dataran rendah sehingga perlu adanya informasi mengenai populasi dan asosiasinya. Penelitian ini bertujuan untuk mendapatkan informasi mengenai populasi dan asosiasi marga Ficus di hutan Gunung Tilu Kabupaten Kuningan Jawa Barat. Penelitian ini menggunakan metode garis berpetak dengan membuat plot memotong garis kontur. Hasil penelitian menunjukan populasi marga Ficus yang terdapat di Gunung Tilu terdiri dari 12 jenis dengan total jumlah individu sebanyak 106 pohon terbagi dalam 9 kelas diameter. Kelas diameter $91-100 \mathrm{~cm}$ memiliki individu terbanyak. Kepadatan populasi marga Ficus sebesar 7,29 individu/hektar. Terdapat 11 pasangan yang menunjukan berbeda nyata dan 55 pasang yang tidak berbeda nyata. Dari 11 pasang tersebut 7 pasangan bersifat positif dan 4 pasangan bersifat negatif. Informasi ini sangat penting bagi pengelolaan dan konservasi tumbuhan Ficus.
\end{abstract}

Kata Kunci: Marga Ficus; asosiasi; hutan dataran rendah

\begin{abstract}
The genus Ficus has a role as a key resource in the lowland forest ecosystem, so there is a need for information about the population and its associations. This study aims to obtain information about the population and the genus Ficus associations in the Gunung Tilu forest in Kuningan, West Java. This study uses a checkered line method by making a plot of cutting contour lines. The results showed the genus Ficus population contained in Gunung Tilu consisted of 12 species with a total number of individuals totaling 106 trees divided into 9 diameter classes. Class diameter 91-100 cm has the most individuals. The population density of the genus Ficus is 7.29 individuals / hectare. There were 11 pairs that were significantly different and 55 pairs that were not significantly different. Of the 11 pairs 7 positive pairs and 4 negative pairs. This information is very important for the management and conservation of Ficus
\end{abstract}

Keywords: The genus Ficus; association; lowland forest

\section{PENDAHULUAN}

Gunung Tilu merupakan kawasan yang terletak di timur Kabupaten Kuningan dan berbatasan langsung dengan Provinsi Jawa Tengah. Tipe hutan Gunung Tilu merupakan hutan dataran rendah yang juga merupakan bagian dari hutan Bukit Pembarisan. Vegetasi hutan dataran rendah memiliki keunikan tersendiri. Dua karakteristik utama yang membedakan hutan dataran rendah dengan bioma terestrial lainnya adalah tingginya kerapatan jenis pohon dan status konservasi tumbuhannya yang hampir sebagian besar dikategorikan jarang secara lokal (Clark et al., 1998). Berdasarkan hasil penelitian Hendrayana et al, (2019) pada kawasan Gunung Tilu terdapat 145 jenis tumbuhan kategori pohon, 159 jenis karegori tiang, 140 jenis kategori pancang dan 141 jenis kategori semai. Jenis-jenis tersebut termasuk dalam 42 Famili. Euphorbiaceae dan moraceae merupakan famili yang memiliki jumlah jenis tumbuhan terbanyak yaitu sebanyak 13 dan 12 jenis. Khusus famili moraceae yang terdapat di gunung Tilu sebagian besar termasuk pada marga Ficus (Hendrayana et al, 2018).

Marga Ficus dapat hidup pada berbagai tipe habitat mulai dari hutan hujan, dibawah kanopi, padang savana, sepanjang aliran sungai serta pada tebing curam (Burrows dan Burrows, 
2003). Selanjutnya menurut Berg dan Corner (2005) di daerah Malesia Ficus dapat ditemukan di hampir semua jenis vegetasi terestrial seperti tanah basah atau kering, daerah berbatu (karang, kapur), hutan primer dan sekunder, pada ketinggian kurang dari $1.500 \mathrm{~m}$ dpl (Yusuf, 2011). Ficus memegang peranan penting dalam ekologi, karena tumbuhan ini dapat hidup di kondisi ekstrim, dan merupakan sumber pangan bagi hewan pemakan buah (frugivora) di sekitarnya (Mawa et al. 2013). Tumbuhan ini mampu berbuah lebat dalam waktu singkat, disaat tumbuhan lain tidak berbuah (Caughlin et al. 2012; Felton et al. 2012). Selain itu, Ficus berperan dalam perbaikan fungsi hutan seiring waktu (Baskara dan Wicaksono 2013).

Berbagai jenis tumbuhan yang terdapat dalam suatu komunitas akan berinteraksi dengan sesama tumbuhan yang ada maupun dengan lingkunganya. Hubungan interaksi antar jenis tumbuhan yang ada akan terlihat dengan ada atau tidaknya jenis tumbuhan yang memperlihatkan tingkat asosiasinya (Ferianita, 2007). Asosiasi merupakan tipe komunitas yang biasanya dicirikan dengan mempunyai komposisi florostik yang relatif konsisten, mempunyai physiognomi serupa meskipun niche berbeda serta penyebaran organisme (Barbour et al, 1987). Interaksiinteraksi yang terjadi dapat berupa interaksi antar individu dari spesies yang sama, dapat juga berupa interaksi antar individu dari spesies yang berbeda. Asosiasi dari dua jenis tumbuhan yang saling berinteraksi dapat bersifat positif atau negatif, dimana nilai positif menunjukan terdapatnya hubungan yang bersifat mutualistik atau saling menguntungkan, sedangkan nilai negatif adalah sebaliknya (Ferianita, 2007). Oleh karena itu, studi vegetasi di kawasan ini sangat perlu dilakukan. Penelitian ini bertujuan untuk menggali informasi mengenai populasi dan asosiasi marga Ficus yang berada di kawasan hutan Gunung Tilu Kabupaten Kuningan.

\section{METODOLOGI PENELITIAN}

Penelitian ini dilaksanakan selama Bulan Agustus 2018 pada kawasan Gunung Tilu Kabupaten Kuningan. Secara administratif wilayah Gunung Tilu termasuk pada Kecamatan
Karangkancana dan Kecamatan Cibingbin Kabupaten Kuningan. Terletak pada posisi geografis $\mathrm{S} 07^{0} 06^{\prime} 12,2^{\prime \prime}$ dan E $108^{0} 41^{\prime}$ ' $47,7^{\prime}$ " sampai S $07^{0} 07^{\prime} 48,1^{\prime \prime}$ dan E $108^{\circ} 41^{\prime} 39,0$ ".

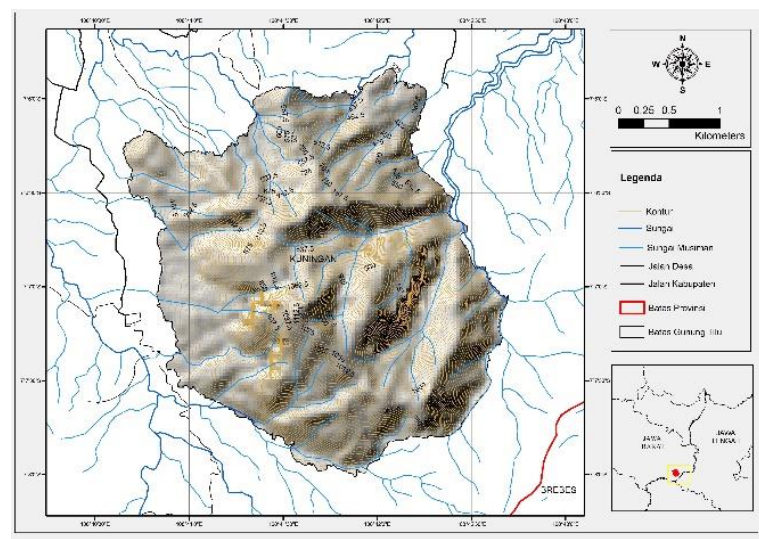

Gambar 1. Peta Lokasi Gunung Tilu Kabupaten Kuningan

Alat yang digunakan adalah: kompas, pita ukur, altimeter, tambang plastik, kamera, alat tulis, tally sheet, ring finder, dan GPS (Global Positioning Systems), Sedangkan Bahan yang digunakan adalah peta kerja (Peta Citra Landsat, Peta Tematik, alkohol, dan bahan yang lainnya

Desain sampling yang digunakan adalah menggunakan metode purposive sampling yaitu pengambilan sampel yang didasarkan atas suatu pertimbangan tertentu seperti sifat-sifat populasi ataupun ciri-ciri yang sudah diketahui sebelumnya. Kemudian ditetapkan jalur memotong garis kontur. Setiap jalur terbagi dari berbagai ketinggian dan pada setiap ketinggian memiliki ditempatkan plot ukur dengan panjang $100 \mathrm{~m}$ dan lebar $20 \mathrm{~m}$.

Menurut Rugayah et al., (2005) data frekuensi, kerapatan dan dominansi tiap jenis pohon yang ditemukan dicacah untuk dianalisis dengan menggunakan Indeks Nilai Penting (INP) dan asosiasi antar jenis-jenis penyusun utama. INP diperoleh dengan formula sebagai berikut: INP $=\mathrm{FR}+\mathrm{KR}+\mathrm{DR}$

FR $($ frekuensi relatif $)=$ FM/Ftotalx $100 \%$

$\mathrm{KR}$ (kerapatan relatif $)=\mathrm{KM} / \mathrm{K}$ total $100 \%$

DR $($ dominansi relatif $)=\mathrm{DM} /$ Dtotalx 10

Analisis asosiasi didasarkan pada kehadiran (presence) dan ketidakhadiran (absence) jenis-jenis Ficus dalam suatu plot sampling selanjutnya dengan menggunakan Tabel Contingency 2x2 (Greig-Smith, 1983). Bentuk tabel Contingency 2x2 untuk 2 jenis sebagai berikut: 


\begin{tabular}{|c|c|c|c|c|}
\hline & \multicolumn{3}{|c|}{ Spesies B } \\
\hline & & Ada & Tidak ada & Jumlah \\
\hline \multirow{3}{*}{$\begin{array}{c}\text { Spesies } \\
\text { A }\end{array}$} & Ada & $\mathrm{a}$ & $\mathrm{b}$ & $a+b$ \\
\hline & $\begin{array}{l}\text { Tidak } \\
\text { ada }\end{array}$ & $\mathrm{c}$ & $\mathrm{d}$ & $c+d$ \\
\hline & Jumlah & $a+c$ & $b+d$ & $\mathrm{~N}=\mathrm{a}+\mathrm{b}+\mathrm{c}+\mathrm{d}$ \\
\hline
\end{tabular}

Keterangan:

$\mathrm{a}=$ Pengamatan jumlah titik pengukuran yang mengandung spesies A dan spesies B,

$\mathrm{b}=$ Pengamatan jumlah titik pengukuran yang mengandung spesies A saja,

$\mathrm{c}=$ Pengamatan jumlah titik pengukuran yang mengandung spesies B saja,

$\mathrm{d}=$ Pengamatan jumlah titik pengukuran yang tidak mengandung spesies A dan spesies $\mathrm{B}$,

$\mathrm{N}=$ Jumlah titik pengamatan .

Untuk mengetahui adanya kecenderungan berasosiasi atau tidak, digunakan Chi-square Test dengan formulasi sebagai berikut:

Chi-squre hitung $=\underline{\mathrm{N}(\mathrm{ad}-\mathrm{bc})^{2}}$

$$
(a+b)(a+c)(c+d)(b+d)
$$

$\mathrm{a}=$ Jumlah titik pengamatan yang mengandung jenis $A$ dan jenis $B, b=$ Jumlah titik pengamatan yang mengandung jenis A saja, $\mathrm{c}=$ Jumlah titik pengamatan yang mengandung jenis $B$ saja, $d=$ Jumlah titik pengamatan yang tidak mengandung jenis $\mathrm{A}$ dan jenis $\mathrm{B}, \mathrm{N}=\mathrm{Jumlah}$ titik pengamatan.

Nilai Chi-square hitung kemudian dibandingkan dengan nilai Chi-square tabel pada derajat bebas $=1$, pada taraf uji 5\% (nilai 1,678). Apabila nilai Chi-square Hitung > nilai Chi-square tabel, maka asosiasi bersifat nyata. Apabila nilai $\mathrm{Chi}$ square Hitung < nilai Chi-square tabel, maka asosiasi bersifat tidak nyata (Ludwig dan Reynold, 1988). Selanjutnya untuk mengetahui tingkat atau kekuatan asosiasi digunakan rumus sebagai berikut:

$$
E(a)=\frac{(a+b)(a+c)}{N}
$$

Notasi yang digunakan mengandung arti yang sama dengan formulasi sebelumnya.

Berdasarkan rumus tersebut, maka terdapat 2 jenis asosiasi yaitu: (1) asosiasi positif, apabila nilai a > E (a) berarti pasangan jenis terjadi bersama lebih sering dari yang diharapkan (2) asosiasi negatif, apabila nilai a $<$ E (a) berarti pasangan jenis terjadi bersama kurang sering dari yang diharapkan Hasil perhitungan asosiasi dari jenis-jenis Ficus disajikan dalam bentuk diagram matriks.

\section{HASIL DAN PEMBAHASAN \\ Populasi Marga Ficus}

Kawasan Gunung Tilu berdasarkan tipe vegetasinya termasuk kedalam tipe vegetasi hutan dataran rendah, yang salah satu puncaknya mencapai ketinggian $1.200 \mathrm{~m}$ dpl. Menurut Kusmana dan Susanti (2015), hutan hujan tropika terbagi menjadi tiga zone; zona I, hutan hujan bawah dengan ketinggian $2-1.000 \mathrm{~m}$ dpl., zona II, hutan hujan tengah dengan ketinggian $1.000-3.000 \mathrm{~m} \mathrm{dpl}$, dan zona III, hutan hujan atas dengan ketiggian di atas 3.000 $\mathrm{m}$ dpl. Jenis Ficus spp yang ditemukan di hutan Gunung Tilu sebanyak 12 jenis dan 106 individu yang tersebar mulai ketinggian $600 \mathrm{~m} \mathrm{dpl}$ sampai dengan $1000 \mathrm{~m}$ dpl. Adapun nama-nama jenis yang termasuk dalam marga Ficus diantaranya kiara beas (Ficus sundaica Blume), kiara bunut (Ficus virens Aiton var. glabella), kiara calodas (Ficus calophylla Blume), kiara karasak (Ficus kurzii King), beringin (Ficus benjamina Linn), kiara bonteng (Ficus globosa Blume), kiara darangdang (Ficus sinuata Thunb), kondang (Ficus variegata Blume), leles (Ficus glandulifera (Wal. Ex. Mix.) King), kiara gembrong (Ficus copiosa Steud), kiara karet (Ficus elastica Roxb. ex Homem), dan hampelas (Ficus ampelas Burm F.). Jumlah jenis Ficus yang ditemukan di Gunung Tilu ini sama dengan jumlah jenis Ficus hasil penelitian Kumar et al., (2011) di Suaka Margasatwa Katerniaghat, Uttar Pradesh India namun lebih kecil dengan keberadaan jenis Ficus spp. di hutan konservasi Prof Soemitro Djojohadikusumo sebanyak 20 jenis (Nur'aini et al, 2013), hutan di Mexico 21 jenis (Serrato et al, 2005), hutan hujan dataran rendah Kalimantan sebanyak 27 spesies (Harrison et al, 2003) dan lahan pertanian (32 jenis) di wilayah Buganda Uganda Tengah (Ipulet, 2008).

Tabel 1. Indeks Nilai Penting marga Ficus di Gunung Tilu Kabupaten Kuningan

\begin{tabular}{lcccc}
\hline \multicolumn{1}{c}{ Nama Ilmiah } & KR & FR & DR & INP \\
\hline Ficus sundaica Blume & 2,27 & 2,41 & 6,49 & 11,2 \\
Ficus virens Aiton var. glabella & 1,99 & 2,71 & 5,89 & 10,6 \\
Ficus calophylla Blume. & 1,51 & 1,81 & 4,83 & 8,15 \\
Ficus kurzii King & 0,85 & 1,21 & 2,66 & 4,72 \\
Ficus benjamina L. & 0,85 & 1,36 & 2,25 & 4,46 \\
Ficus globosa Blume & 0,66 & 0,90 & 1,20 & 2,27 \\
Ficus sinuata Thunb & 0,47 & 0,60 & 1,02 & 2,10 \\
Ficus variegata Blume & 0,47 & 0,75 & 0,20 & 1,43 \\
\hline
\end{tabular}




\begin{tabular}{lcccc}
\hline Ficus glandulifera & 0,38 & 0,60 & 0,32 & 1,31 \\
Ficus copiosa Steud. & 0,28 & 0,30 & 0,67 & 1,25 \\
Ficus elastica Roxb. ex Hornem & 0,10 & 0,15 & 0,31 & 0,55 \\
Ficus ampelas Burm F. & 0.10 & 0,15 & 0,06 & 0,30 \\
\hline KR = Kerapatan Relatif; FR = Frekwensi Relatif; \\
DR = Dominansi Relatif; INP = Indeks Nilai Penting
\end{tabular}

Hasil perhitungan INP (Tabel 1) menunjukan dari 12 jenis Ficus tersebut sebagian besar tidak termasuk pada jenis pohon yang dominan karena mempunyai nilai INP di bawah 10, kecuali jenis Ficus sundaica Blume $(11,2)$ dan jenis Ficus virens Aiton var. glabella $(10,6)$. Jumlah individu Ficus sundaica yang ditemukan sebanyak 24 indivisu yang tersebar pada 16 plot sampling. Jenis ini berhabitus pohon dengan bentuk daun lebar ditengah (ovate), mempunyai pertulangan daun menyirip, serta buah pada ujung tangkai. Menurut Berg dan Corner, (2005) Ficus sundaica termasuk dalam habitus pohon setinggi $35 \mathrm{~m}$, hemi-epifit. Terestrial. Rambut internal tidak ada. Daun disusun secara spiral; stipules 1-3 (-5) cm panjang, glabarous (atau putih puberulous), caducous, sering dengan bagian median yang berbeda. Ovarium sebagian berwarna merah. Daerah penyebaran meliputi Kalimantan, Sumatera Jawa, Bali, Maluku, Malaya, Philippines, Thailand. Sedangkan Ficus virens berbentuk pohon, dengan bentuk daun lebar ditengah (elliptic), pertulangan daun menyirip, buah pada ranting.

Ficus virens yang ditemukan sebanyak 21 individu tersebar pada 18 plot sampling. Jenis ini sama halnya pendapat dari berhabitus pohon setinggi $35 \mathrm{~m}$, hemi-epiphytic, gugur. Rambut internal melimpah (chaffy). Daun disusun secara spiral; Stipules 0,3-1,5 (pada pembukaan tunas sampai 8) $\mathrm{cm}$ panjang, glabrous atau jarang sampai puberulous padat, irama atau subpersisten pada puncak ranting berdaun dan biasanya membentuk tunas terminal ovoid. Ovarium berwarna merah kecokelatan. Sebaran meliputi Kalimantan, Sumatera, Jawa, Bali, Maluku, Sulawesi, Malaya, Papua Nugini, Philipina, Thailand, dan Vietnam. (Berg dan Corner, 2005).

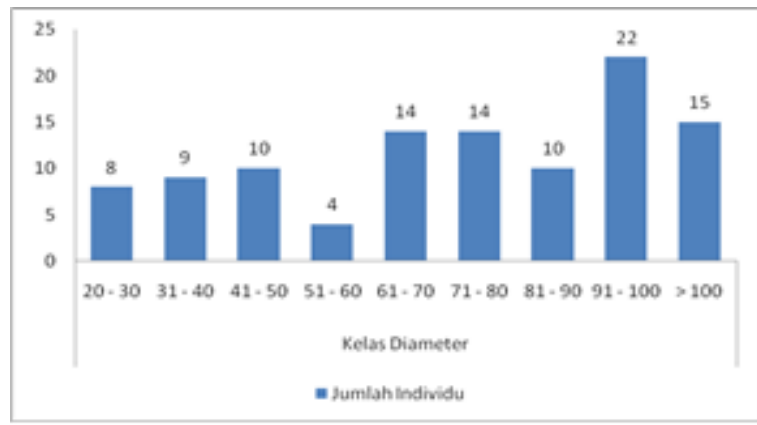

Gambar 2. Diagram batang sebaran diameter marga Ficus

Berdasarkan pengelompokan kelas diameter marga Ficus yang terdapat di Gunung Tilu Kabupaten Kuningan pada kelas diameter 91-100 $\mathrm{cm}$ yang mempunyai individu terbesar yaitu sebanayak 22 individu, sedangkan kelas diameter 51-60 cm mempunyai jumlah individu terkecil yaitu berjumlah 4 individu. Sedangkan secara keseluruhan kerapatan jenis marga Ficus sebesar 7,29 individu/hektar.

\section{Asosiasi diantara marga Ficus}

Hasil perhitungan (Tabel 2) terdapat 66 pasangan marga Ficus yang diasosiasikan dan terdapat 55 pasang yang tidak berbeda nyata (tidak berasosiasi) karena mempunyai nilai Chisquare hitung kurang dari Chi-square tabel, sedangkan 11 pasang lagi mempunyai hubungan yang berbeda nyata karena nilai Chi-square hitung lebih dari Chi-square tabel. Dari ke 11 pasangan itu adalah pasangan (1) F. sundaica dengan F. copiosa $(4,174)$, (2) F. sundaica dengan F. ampelas (2,022), (3) F. virens dengan F. copiosa (3,765), (4) F. calophylla dengan F. elastic $(3,064),(5)$ F. globosa dengan F. copiosa $(2,683)$, (6) F. sinuata dengan F. copiosa $(4,743)$, (7) F. glandulifera dengan F. ampelas $(11,234),(8)$ F. sundaica dengan F. calophylla $(2,118)$, (9) F. virens dengan F. glandulifera $(2,618),(10)$ F. calophylla dengan F. kurzii $(3,200)$, dan (11) F. calophylla dengan F. globosa $(2,286)$.

Marga Ficus yang tidak berasosiasi diakibatkan karena tidak dipengaruhi oleh keberadaan spesies-spesies tersebut yang memiliki toleransi yang tinggi terhadap berbagai kondisi lingkungan. Menurut Sykora et al. (2014) kondisi fisik tanah mempengaruhi komposisi jenis tumbuha yang berasosiasi karena iklim mikro (cahaya, radiasi, angin, temperatur dan kelembaban). 
Tabel 2. Hasil perhitungan asosiasi marga Ficus di Gunung Tilu

\begin{tabular}{|c|c|c|c|c|}
\hline Jenis & $\begin{array}{c}\mathrm{X}^{2} \mathrm{t} \\
(5 \%) \\
\end{array}$ & $\mathrm{X}^{2} \mathrm{t}$ & $\begin{array}{c}\text { Tipe } \\
\text { Asosiasi }\end{array}$ & E(a) \\
\hline \multicolumn{5}{|l|}{ F. sundaica dengan F. virens } \\
\hline F. sundaica dengan F. calophylla & & & & \\
\hline F. sundaica dengan F. kurzii & 1,678 & $0.400^{\text {ns }}$ & td & 6 \\
\hline F. sundaica dengan F. benjamina & 1,678 & $2.118^{*}$ & - & 4,08 \\
\hline F. sundaica dengan F. globosa & 1,678 & $0.052^{\mathrm{ns}}$ & td & 2,66 \\
\hline F. sundaica dengan F. sinuata & 1,678 & $0.615^{\mathrm{ns}}$ & $\mathrm{td}$ & 3 \\
\hline F. sundaica dengan F. variegata & 1,678 & $0.857^{\mathrm{ns}}$ & $\mathrm{td}$ & 2 \\
\hline F. sundaica dengan F. glandulifera & 1,678 & $0.545^{\mathrm{ns}}$ & $\mathrm{td}$ & 1,33 \\
\hline F. sundaica dengan F. copiosa & 1,678 & $0.447^{\mathrm{ns}}$ & $\mathrm{td}$ & 1,66 \\
\hline F. sundaica dengan F. elastica & 1,678 & $0.136^{\mathrm{ns}}$ & $\mathrm{td}$ & 1,33 \\
\hline F. sundaica dengan F. ampelas & 1,678 & $4.174^{*}$ & + & 0,66 \\
\hline F. virens dengan F. calophylla & 1,678 & $0.511^{\mathrm{ns}}$ & $\mathrm{td}$ & 0,33 \\
\hline F. virens dengan F. kurzii & 1,678 & $2.022^{*}$ & + & 0,33 \\
\hline F. virens dengan F. benjamina & 1,678 & $0.030^{\mathrm{ns}}$ & $\mathrm{td}$ & 4,25 \\
\hline F. virens dengan F. globosa & 1,678 & $0.640^{\mathrm{ns}}$ & $\mathrm{td}$ & 3 \\
\hline F. virens dengan F. sinuata & 1,678 & $0.082^{\mathrm{ns}}$ & $\mathrm{td}$ & 3,37 \\
\hline F. virens dengan F. variegata & 1,678 & $0.051^{\mathrm{ns}}$ & $\mathrm{td}$ & 2,25 \\
\hline F. virens dengan F. glandulifera & 1,678 & $0.259^{\mathrm{ns}}$ & td & 1,5 \\
\hline F. virens dengan F. copiosa & 1,678 & $1.206^{\mathrm{ns}}$ & td & 1,87 \\
\hline F. virens dengan F. elastica & 1,678 & $2.618^{*}$ & - & 1,5 \\
\hline F. virens dengan F. ampelas & 1,678 & $3.765^{*}$ & + & 0,70 \\
\hline F. calophylla dengan F. kurzii & 1,678 & $0.613^{\mathrm{ns}}$ & $\mathrm{td}$ & 0,37 \\
\hline F. calophylla dengan F. benjamina & 1,678 & $0.613^{\text {ns }}$ & $\mathrm{td}$ & 0,37 \\
\hline F. calophylla dengan F. globosa & 1,678 & $3.200^{*}$ & - & 2 \\
\hline F. calophylla dengan F. sinuata & 1,678 & $1.140^{\mathrm{ns}}$ & $\mathrm{td}$ & 2,25 \\
\hline F. calophylla dengan F. variegata & 1,678 & $2.286^{*}$ & - & 1,5 \\
\hline F. calophylla dengan F. & 1,678 & $1.455^{\mathrm{ns}}$ & $\mathrm{td}$ & 1 \\
\hline glandulifera & 1,678 & $0.074^{\mathrm{ns}}$ & td & 1,25 \\
\hline F. calophylla dengan F. copiosa & 1,678 & $1.455^{\mathrm{ns}}$ & $\mathrm{td}$ & 1 \\
\hline F. calophylla dengan F. elastica & 1,678 & $0.696^{\mathrm{ns}}$ & $\mathrm{td}$ & 0.5 \\
\hline F. calophylla dengan F. ampelas & 1,678 & $3.064^{*}$ & + & 0,25 \\
\hline F. kurzii dengan F. benjamina & 1,678 & $0.340^{\mathrm{ns}}$ & $\mathrm{td}$ & 0,25 \\
\hline F. kurzii dengan F. globosa & 1,678 & $0.246^{\mathrm{ns}}$ & td & 1,5 \\
\hline F. kurzii dengan F. sinuata & 1,678 & $0.000^{\mathrm{ns}}$ & $\mathrm{td}$ & 1 \\
\hline F. kurzii dengan F. variegata & 1,678 & $0.218^{\mathrm{ns}}$ & $\mathrm{td}$ & 0,66 \\
\hline F. kurzii dengan F. glandulifera & 1,678 & $0.045^{\text {ns }}$ & $\mathrm{td}$ & 0,83 \\
\hline F. kurzii dengan F. copiosa & 1,678 & $0.873^{\text {ns }}$ & $\mathrm{td}$ & 0,66 \\
\hline F. kurzii dengan F. elastica & 1,678 & $1.670^{\mathrm{ns}}$ & $\mathrm{td}$ & 0,33 \\
\hline F. kurzii dengan F. ampelas & 1,678 & $0.204^{\mathrm{ns}}$ & $\mathrm{td}$ & 0,16 \\
\hline F. benjamina dengan F. globosa & 1,678 & $0.204^{\mathrm{ns}}$ & $\mathrm{td}$ & 0,16 \\
\hline F. benjamina dengan F. sinuata & 1,678 & $0.957^{\text {ns }}$ & $\mathrm{td}$ & 1,12 \\
\hline F. benjamina dengan F. variegata & 1,678 & $1.007^{\text {ns }}$ & $\mathrm{td}$ & 0,75 \\
\hline F. benjamina dengan $\mathrm{F}$. & 1,678 & $0.006^{\mathrm{ns}}$ & $\mathrm{td}$ & 0,93 \\
\hline glandulifera & 1,678 & $0.873^{\mathrm{ns}}$ & $\mathrm{td}$ & 0,66 \\
\hline F. benjamina dengan F. copiosa & 1,678 & $1.670^{\mathrm{ns}}$ & $\mathrm{td}$ & 0,33 \\
\hline F. benjamina dengan F. elastica & 1,678 & $0.236^{\mathrm{ns}}$ & $\mathrm{td}$ & 0,18 \\
\hline F. benjamina dengan F. ampelas & 1,678 & $0.236^{\mathrm{ns}}$ & td & 0,18 \\
\hline F. globosa dengan F. sinuata & 1,678 & $0.623^{\text {ns }}$ & $\mathrm{td}$ & 0.5 \\
\hline F. globosa dengan F. variegata & 1,678 & $0.797^{\mathrm{ns}}$ & td & 0,62 \\
\hline F. globosa dengan F. glandulifera & 1,678 & $0.623^{\mathrm{ns}}$ & $\mathrm{td}$ & 0,5 \\
\hline F. globosa dengan F. copiosa & 1,678 & $2.683^{*}$ & + & 0,25 \\
\hline F. globosa dengan F. elastica & 1,678 & $0.146^{\mathrm{ns}}$ & td & 0,12 \\
\hline F. globosa dengan F. ampelas & 1,678 & $0.146^{\mathrm{ns}}$ & td & 0,12 \\
\hline F. sinuata dengan F. variegata & 1,678 & $0.507^{\mathrm{ns}}$ & $\mathrm{td}$ & 0,41 \\
\hline F. sinuata dengan F. glandulifera & 1,678 & $0.397^{\text {ns }}$ & $\mathrm{td}$ & 0,33 \\
\hline F. sinuata dengan F. copiosa & 1,678 & $4.743 *$ & + & 0,16 \\
\hline F. sinuata dengan F. elastica & 1,678 & 0.093 ns & $\mathrm{td}$ & 0,08 \\
\hline F. sinuata dengan F. ampelas & 1,678 & $0.119^{\mathrm{ns}}$ & td & 0,10 \\
\hline F. variegata dengan F. glandulifera & 1,678 & $0.507^{\mathrm{ns}}$ & td & 0,41 \\
\hline F. variegata dengan F. copiosa & 1,678 & $0.243^{\mathrm{ns}}$ & td & 0,20 \\
\hline F. variegata dengan F. elastica & 1,678 & $0.119^{\mathrm{ns}}$ & td & 0,10 \\
\hline F. variegata dengan F. ampelas & 1,678 & $0.119^{\mathrm{ns}}$ & td & 0,10 \\
\hline F. glandulifera dengan F. copiosa & 1,678 & $0.190^{\text {ns }}$ & td & 0,16 \\
\hline F. glandulifera dengan F. elastica & 1,678 & $0.093^{\mathrm{ns}}$ & $\mathrm{td}$ & 0,08 \\
\hline F. glandulifera dengan F. ampelas & 1,678 & $11.234 *$ & + & 0,08 \\
\hline F. copiosa dengan F. elastica & 1,678 & $0.044^{\mathrm{ns}}$ & $\mathrm{td}$ & 0,04 \\
\hline F. copiosa dengan F. ampelas & 1,678 & $0.044^{\mathrm{ns}}$ & $\mathrm{td}$ & 0,04 \\
\hline F. elastica dengan F. ampelas & 1,678 & $0.022^{\mathrm{ns}}$ & $\mathrm{td}$ & 0,02 \\
\hline
\end{tabular}

Keterangan : +: asosiasi positif, -: asosiasi negatif, *: Berbeda nyata pada taraf uji $5 \%$, td: Tidak dihitung, ns: Tidak berbeda nyata

Dari 11 pasangan yang berbeda nyata terdapat 7 pasang yang berasosiasi positif $(+)$ yaitu (1) F. sundaica dengan F. copiosa; (2) F. sundaica dengan $\mathrm{F}$. ampelas; (3) F. virens dengan F. copiosa; (4) F. calophylla dengan F. elastic; (5) F. globosa dengan F. copiosa; (6) F. sinuata dengan F. copiosa; (7) F. glandulifera dengan F. ampelas. Menurut Barbour et. al. (1999), menyebutkan bahwa bila jenis berasosiasi secara positif maka akan menghasilkan hubungan spasial positif terhadap pasangannya. Jika satu pasangan didapatkan dalam sampling, maka kemungkinan besar akan ditemukan pasangan lainnya tumbuh di dekatnya. Windusari et al. (2011) menunjukkan ada spesies yang berasosiasi karena kedua spesies yang berasosiasi tersebut menyukai tempat dengan parameter lingkungan yang hampir sama, misalnya tempat yang cenderung basah dan intensitas cahaya matahari yang tinggi hingga agak teduh.

Pasangan yang berasosiasi negatif (-) yaitu (1) F. sundaica dengan F. calophylla; (2) F. virens dengan F. glandulifera; (3) F. calophylla dengan F. kurzii; dan (4) F. calophylla dengan F. globosa. Hal ini membuktikan bahwa pasangan tersebut tidak menunjukkan adanya toleransi untuk hidup bersama pada area yang sama atau tidak ada hubungan timbal balik yang saling menguntungkan, khususnya dalam pembagian ruang hidup. Menurut Mueller-Dombois dan Ellenberg (1974).

Selanjutnya Sofiah et al. (2013) menjelaskan pasangan spesies tidak selalu menghasilkan hubungan yang positif. Spesies tumbuhan yang memiliki frekuensi kehadiran yang tinggi, tidak selalu memberikan nilai asosiasi positif tinggi dengan spesies lain. Demikian halnya, spesies yang memiliki frekuensi kehadiran yang rendah tidak selalu memberikan asosiasi negatif dengan spesies lain. Pratama et al. (2012) menjelaskan Asosiasi negatif menunjukkan tidak adanya toleransi untuk hidup bersama pada area yang sama atau tidak adanya hubungan timbal balik yang saling menguntungkan. Keberadaan berbagai spesies dalam komunitas tumbuhan menimbulkan peluang terjadinya kompetisi, hal ini dijelaskan oleh Solikin (2015) keberadaaan beragam jenis tumbuhan dalam komunitas menyebabkan adanya kompetisi antar individu dalam spesies atau antar spesies yang pada akhirnya membentuk komposisi dan dominansi yang beragam.

\section{SIMPULAN}

Populasi marga Ficus yang terdapat di Gunung Tilu terdiri dari 12 jenis dengan total jumlah individu sebanyak 106 pohon terbagi dalam 9 kelas diameter. Kelas diameter 91-100 $\mathrm{cm}$ memiliki individu terbanyak. Kepadatan populasi marga Ficus sebesar 7,29 
individu/hektar. Terdapat 11 pasangan yang menunjukan berbeda nyata dan 55 pasang yang tidak berbeda nyata. Dari 11 pasang tersebut 7 pasangan bersifat positif dan 4 pasangan bersifat negatif.

\section{REFERENSI}

Barbour, B.M., J.K. Burk, and W.D. Pitts. 1999. Terrestrial Plant Ecology. New York: The Benjamin/Cummings.

Baskara M, Wicaksono KP. 2013. Tumbuhan Ficus: Penjaga Keberlanjutan Budaya dan Ekonomi di Lingkungan Karst. Temu Ilmiah IPLBI 2013 C: 21-25.

Berg, C. C. dan E. J. H Corner, 2005. Ficus-Moraceae. Flora Malesiana, Series I, 17: 1-730.

Burrows, J. and Burrows, S. 2003. Figs of Southern and South-Central Africa Umdaus Press, Hatfield.

Caughlin TT, Ganesh T, Lowman MD. 2012. Sacred fig trees promote frugivore visitation and tree seedling abundance in South India. Curr Sci 102 (6): 918-922.

Clark, D.B., Clark, D.A., dan Read, J.M. 1998. Edaphic variation and the mesoscale distribution of tree species in a neotropical rain forest. Journal of Ecology 86: 101112.

Felton AM, Felton A, Rumiz DI, Villaroel N, Chapman CA, Lindenmayer DB. 2012. Commercial harvesting of Ficus timberAn emerging threat to frugivorous wildlife and sustainable forestry. Biol Conserv 159: 96-100.

Ferianita, 2007 Metode sampling Bioekologi. Bumi Aksara. Jakarta

Greg-Smith, P. 1983. Quantitative plant ecology. Third edition. Berkeley and Los Angeles, CA: University of California Press. 359 p.

Harrison, Rhet D. 2003, Fig wasp dispersal and the stability of a keystone plant resource in Borneo. Proc. R. Soc. Lond. B (Suppl.) 270, S76-S79.

Hendrayana, Y, Adhya I, Ismail, AY, 2018. Diversity and Carbon Stocks of Genus Ficus In Gunung Tilu Kuningan District, West Java Province, Indonesia. Journal of Forestry and Environment 01 (2018) 25 29.

Hendrayana Y, Widodo P, Kusmana C, Widhiono I, 2019. Diversity and distribution of figs (Ficus spp.) across altitudes in Gunung Tilu, Kuningan, West Java, Indonesia. Biodiversitas Vol. 20 No. 6 (1568-1574)

Ipulet P, 2008. Diversity of Genus Ficus L. (Moraceae) in farmlands and pastoral areas in Buganda region, central Uganda. African Journal of Ecology. 46 (Suppl. 1), $52-58$.

Kumar A, Bajpai O, Mishra A.K, Sahu N, Behera S.K, Chaudhary L.B. 2011. Assessment of Diversity in the Genus Ficus L. (Moraceae) of Katerniaghat Wildlife Sanctuary, Uttar Pradesh, India. American Journal of Plant Sciences, 2011, 2, 78-92.

Kusmana C, dan Susanti S. 2015. Komposisi dan struktur tegakan hutan alam di hutan pendidikan gunung Walat, Sukabumi. Jurnal Silvikultur Tropika, 5(3): 210-217

Ludwig, J.A dan J.F. Reynolds, 1988. Statistical Ecology. 2nd ed. London: Edward Arnold (Publisher) Co. Ltd.

Mawa S, Husain K, Jantan I. 2013. Ficus carica L. (Moraceae): Phytochemistry, Traditional Uses and Biological Activities. Evid-Based Compl Altern Med. Article ID 974256, 8 pages.

Mueller-Dombois, D. and H. Ellenberg. 1974. Aims and Methods of Vegetation Ecology. Toronto: John Wiley \& Sons Inc.

Nur'aini, Syamsuardi, Arbain A, 2013. Tumbuhan Ficus L. (Moraceae) di hutan konservasi Prof. Soemitro Djojohadikusumo, PT. Tidar Kerinci Agung (TKA), Sumatera Barat. Jurnal Biologi Universitas Andalas. 235-241.

Pratama, Bayu Arief, Laode Alhamd, Joeni Setijo Rahajoe, 2012. Asosiasi dan Karakterisasi Tegakan Pada Hutan Rawa Gambut di Hampagen, Kalimantan tengah. J. Tek. Ling. Edisi Khusus Hari lingkungan Hidup:69-76

Rugayah, E.A. Widjaja, dan Praptiwi. 2005. Pedoman Pengumpulan Data.

Serrato A, Manriquez G.I, Oyama K. 2005, Biogeography and conservation of genus Ficus (Moraceae) in Mexico. Juornal of Biogeography 31, 475-485.

Sofiah, Siti, Dede Setiadi, Didik Widyatmoko, 2013. Pola Penyebaran, Kemelimpahan, dan Asosiasi Bambu pada Komunitas Tumbuhan di Taman Wisata Alam Gunug 
Baung Jawa Timur. Berita Biologi. Jurnal Ilmu-Ilmu Hayati. 12(2): 239 -247.

Solikin, 2015. Komposisi Jenis-jenis Tumbuhan pada Dua Komunitas Tempat Tumbuh Stachytar phetajamaicensis (L.) Vahl. Di Desa Gajahrejo Kabupaten Pasuruan dan Desa Jeru Kabupaten Malang (Elektronik version). Bioeksperimen. 1(2): 28-36.

Sykora, K.V., J. C. van der Bogert, F. Berendse, (2004). Change in Soil and Vegetation During Dune Slack Succession (Elektronik version). J. Veget. Science, 15:209-218

Windusari, Yuanita, Robyanto H. Susanto, Zulkifli Dahlan, Wisno Susetyo, 2011. Asosiasi Jenis pada Komunitas Vegetasi Suksesi di Kawasan PengendapanTailing Tanggul Ganda di Pertambangan PTFI Papua. Jurnal Ilmiah Ilmu-Ilmu Hayati Biota. 16(2): 242-251.

Yusuf, Rizali. 2011. Sebaran Ekologi Dan Keanekaragaman Ficus Spp. di Indonesia Berk. Penel. Hayati Edisi Khusus: 5A (83-91), 2011. 